IRSTI 16.01.11

\author{
Aimagambetova M.M. ${ }^{1}$, Koc K. ${ }^{2}$, \\ ${ }^{1} \mathrm{PhD}, \mathrm{A} /$ Professor of Al-Farabi Kazakh National University, Kazakshtan, Almaty, \\ ${ }^{2} \mathrm{PhD}, \mathrm{A} /$ Professor of Mugla Sitki Kocman University, Turkey, Mugla, \\ e-mail: aimagambetovamalika@gmail.com,kenankoc2030@hotmail.com
}

\title{
HEADLINE AS A COMPONENT OF PUBLICISTIC TEXT
}

The headline of a newspaper article or news site is the leading component of a text, which takes a strong position by naming it, giving initial information about it, attracting the attention of a potential reader, recruiting it and encouraging them to refer to the entire text. The expressive possibilities of the headline as a semiotic unit are numerous, it can be used all the resources of expressive speech. It is one of the means of attracting attention to the published material. It is not only precedes the article, carries some information about the content of the material, but also reports on the meaning, nature and importance of the events.

Key words: headline, article, news site, the phraseological unit, transformation.

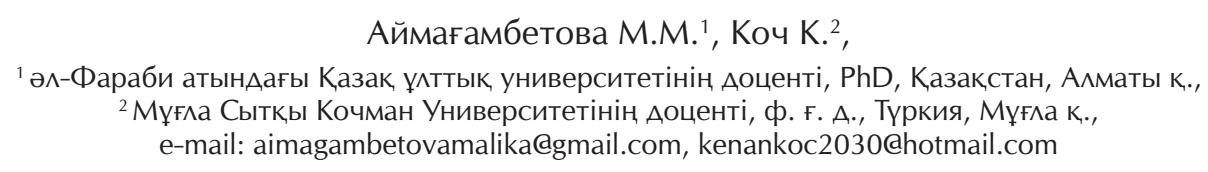

Тақырып - публицистикалық мәтіннің құрамдас бөлігі

Газет мақаласы мен жаңалықтар сайтының тақырыбы дегеніміз - оқырман мен көрерменге алғашқы ақпарат беріп, назарын аударып, толық мәтінді оқуға шақырып тұратын, мықты позициясы бар негізгі мәтіннің басты құрамдас бөлігі. Тақырып мәнерлілігінің семиотикалық бірлік ретіндегі мүмкіндіктері кең болғандықтан, мұнда мәнерлеп сөйлеудің барлық, ресурстары қолданылады. Тақырып - жарияланатын мақалаға назар аудартудың бірден-бір жолы. О^ мақаланың негізгі мазмұны туралы ескертіп қана қоймай, ондағы оқиғаның мағынасы, сипаты мен мәні туралы да ақпарат береді.

Түйін сөздер: тақырыпша, мақала, жаңалықтар сайты, фразеологизм, трансформация.

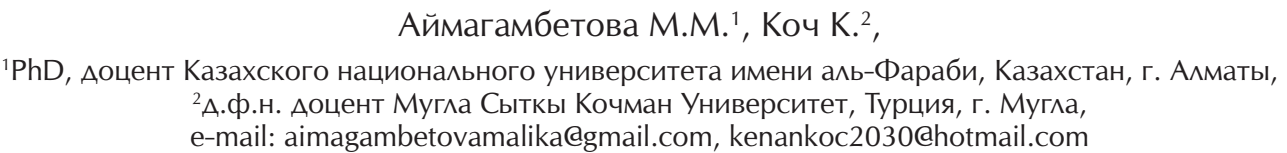

Аймагамбетова М.M. ${ }^{1}$, Коч K. ${ }^{2}$,

'PhD, доцент Казахского национального университета имени аль-Фараби, Казахстан, г. Алматы, ${ }^{2}$ А.ф.н. Аоцент Мугла Сыткы Кочман Университет, Турция, г. Мугла, e-mail: aimagambetovamalika@gmail.com, kenankoc2030@hotmail.com

\section{Заголовок как компонент публицистического текста}

Заголовок газетной статьи или новостного сайта - это ведущий компонент текста, который занимает сильную позицию, называя его, давая первоначальную информацию о нем, привлекая внимание потенциального читателя, вербуя его и побуждая обратиться ко всему тексту. Выразительные возможности заголовка как семиотической единицы многочисленны, в нем могут быть использованы все ресурсы выразительной речи. Он является одним из средств привлечения внимания к публикуемому материалу. Он не только предваряет статью, несёт некоторую информацию о содержании материала, но и сообщает о значении, характере и степени важности событий.

Кмючевые слова: заголовок, статья, новостной сайт, фразеологизм, трансформация. 


\section{Introduction}

Currently, the media are so firmly established in life that they have become a powerful means of influencing the human mind, and, accordingly, on the further outlook and behavior of people. Being dynamic in its essence, the language of mass media most quickly reacts to all changes in the society, reflecting the state of public consciousness, influencing its formation and development.

Exposure to non-fiction text in the recipient and ways to attract the reader's attention has always aroused great interest not only linguists, but also philosophers, psychologists, journalists (Zh. Amanbaeva, Z.D. Blaskowski, E.V. Gorin, T.P. Zorina, L.G., Kayda, V.G. Kostomarov, E.A. Lazareva, A.S. Podchasov, N.In. Rachuk, B.H. Raimbekova, S.K. Roshchin, G.Y. Solganik, A.V. Tulle, M.J. Adams, N. Bagnall, A. Bell, etc.).

The modern journalistic text based on the "pyramid principle». Events in the text unfold from the result, the event, its final scene to the causes and origins of what happened. Consequently, the reader descends from the most important information (problems) to less vivid facts and pays attention to the most important elements of the text. At the same time, you can interrupt reading at any time, since the main idea of the article is already familiar to the reader thanks to the title of the article, which contains its main meaning.

Mandatory parts of the newspaper article are the title, subtitle, introduction (lead), main part and conclusion. A lead is the paragraph that precedes the news and contains answers to the most important questions, which often highlighted in bold, becoming the most visible component of the article (Amzin. http://alex-alex.ru). If the task of the headline is to attract the reader, the function of the lead is to keep his attention.

\section{Experiment and discussion}

The headline is a complex structural and semantic whole that includes semantic, emotional, psychological and social aspects. In the scientific literature on headings, there are different views on the interpretation of the term «headline». This is works of A.E. Dolgireva, T.V. Vasilyeva, E.B. Barannikova, Z.Y. Krasnevskyi and others.

In this paper, the choice made in favor of the term «headline». We came to this choice because of the analysis of the relevant literature and our own observations on the features of the headlines and their functions.
Despite the fact that the language of the newspaper became the object of study of linguists in the 20s of XX century, only in 60-70s scientists turned to the problem of the headline. The study of the problem of headings was mainly due to their syntactic and stylistic features; in the 80 s, linguists were studying the connection of the headline with the beginning and ending - the foregrounding elements of the structure of the text. At the same time, special attention paid both to the language features of the newspaper and to extra linguistic factors (political orientation, readership, etc.).

In recent years, much attention paid to the study of the headline as a precedent phenomenon. «Precedent texts as stable nominative-emotive components in pre-speech readiness» (Karaulov, 2003: 220) are widely used in the process of creating journalistic text and headers (E.A. Zhuravleva, E.A. Zemskaya, J.D. Kaparova, S.I. Kuzminsky, E.A. Nakhimova, G.G. Slyshkin, E.P. Chernogorodova).

From the reader today requires the ability to relate the text to another text. As noted by S.A. Sabitova: «more and more often in the language of the media of the Republic of Kazakhstan there are language forms, followed by a kind of «text trail», which accompanies all of their usages. To understand them, of course, native speakers need appropriate cultural experience. Without knowledge of what is the essence of this «trail», information for the addressee is not available in whole or in part, since the use of precedent texts in oral and written speech implement the process of reviving the accumulated cultural baggage». The headline, in particular, is a kind of «relay», by means of which the author is able to turn on or turn off the imagination and interest of the reader, to actualize his knowledge. In this precedent texts help journalist.

Among the scientists who considered the headlines from a semantic point of view and their functioning, there were three approaches:

Approach 1. A headline is a self-contained unit that is detached from the text and only points to it.

Foreign linguists analyze the headline in isolation from the text, i.e. as an independent phenomenon. E. Agricola distinguishes «the headline of the text» and «the text itself», considering them two separate, independent from each other units, which are «paraphrases» of each other (Agricola, 1979: 21). R. Ernst in his work distinguishes the headline as «a separate text, which has different functions, is allocated a certain font and is separated from the rest of the text» (Ernst, 2005: 4). Headings are similar to those types of language expression that occur in catalogs, dictionaries, telegrams, etc. 
Approach 2. Headline is an integral element of the text, and connected with it in the structural and semantic meaning.

O.P. Semenets in the study on the analysis of the language newspaper gives the headline as «an integral part of a newspaper article, where a journalist takes into account the main text categories» (Semenets, 2004: 15-17). M.A. Stepanov considers it as «a special tool for extracting themes and subtopics, topics from the text» (Stepanova, 2006: 60).

According to D.E. Rosental, the headline in the newspaper, in contrast to the names of radio and television programs, is a communicative unit, it briefly informs the reader about the content of newspaper material, informs about the meaning, nature and importance of the events reflected in the pages of the newspaper. Moreover, it is often possible to judge about the author's attitude to the described events, but also about the position of the editorial staff from the headline of the article, the reportage (Rozental, 1981: 205).

The headline presented as an important organizing element of the text in the works of some researchers, which «plays an important role in the transmission in concentrated form of the main themes and ideas of the text» (Stepanova, 2006: 60).R.T. Kozhabekova in her dissertation writes that the headline is not only the title of the article, but also a summary of the material (Kozhabekova, 2002: 21).

Approach 3. The headline can consider depending on the text and independently. V.P. Vomperskii proposed this approach. He notes the duality of the nature of the headline, which can see independently as part of the text (Vomperskiy, 1966: 84).

V.G. Kostomarov supports this position, arguing that the headline not only depends on the text, but at the same time can «live outside the connection to the article $<\ldots>$ as an independent result of worded form» (Kostomarov, 1965: 181).

E.A. Lazareva studyed it «on the one hand, as a language structure, anticipating text, standing above and in front of him, highlights the special status of the headline. Therefore, the headline perceived as a speech element that is outside the text and has certain independence. On the other hand, the headline is a full - fledged component of the text, which is included in it and associated with other components of the whole work. Title is a definite plan for the division of the text, spatialfunctional, or the architectonics of the text» along with a beginning, middle, and ending (Lazareva, 1989: 3).
Newspaper headlines differ from the titles of works of art in that they are correlated not only with the text of the article or the content, but also with the outside world; this explains their greater autonomy in comparison with the headline of the work of art.

The validity of these approaches to the study of the headlines are thoroughly proved in the works of many scientists. One of the reasons for the lack of unity in the interpretation of the phenomenon of the headline is the feature of its functioning as a mandatory component of the text. For example, a title is not required for poetic texts. Another reason is the close semantic correlation of the headline with the main text. The researchers note that the headline is the semantic equivalent of the text and it considers as a kind of key to its understanding.

The headline in a concise form is that represents the main idea of the article and intrigues the reader as well as affects the popularity and competitiveness of the entire newspaper. Research psychologists have shown that about $80 \%$ of readers pay attention only to the headlines. Journalist should not only convey the message and content of the article in a few words of the headline, but also to attract, interest the reader. It is focused on the following text and acts as its first sign; «autocentric» to a greater extent than other elements of the text, expressing the author's intention, the author's vision of the world, the specifics and implementation of features in different linguistic and cultural societies. Moreover, as a rule, it is written in "telegraphic language»: extremely small phrases, which omit all secondary elements and use common vocabulary and simple grammatical means. It consists of the keywords of the article, which selects uniquely to express the content of the article. It needs to be catchy, concise, contain no more than 5-6 words should not have complex designs and symbols, as «a short headline is better perceived and remembered» (Valgina, 1994: 61).

Short, punch, saturation of realities, phraseological units are the integral features of newspaper headlines of modern periodicals. Journalists use well known to the reader words and expressions, phraseological units, proverbs and sayings, idioms and quotes, changing them or leaving them in their original form. This kind of headline creates a second semantic plan.

There are many classifications and types of headlines in linguistics. In the classification of E.A. Lazareva they differ depending on the number of elements of semantic scheme of the text (unidirectional and complex), according to the expression of any semantic element of the 
work (full-informative, incomplete and dotted) (Lazareva, 1989: 28). Researcher M.I. Shostak allocates narrative headings, the header statement, the header summary, header-paradox, the names in the headline (reference of the event's participants), the title-quote, game title. It was suggested three types: a direct reflection of the theme, a direct reflection of the ideas and mediated reflection of the ideological and thematic decisions through a journalistic way. The functional-semantic typology of information headings of mass media was proposed by Green (Rozental, 1981: 205). They are allocated: approximately-information, actually-information and estimated-information titles.

In the conditions of wide dissemination and development of information technologies, mass media have an increasing influence on the formation of public consciousness and the stability of speech skills and preferences of readers. Newspaper and magazine usage largely forms the «style of the reader» and changes to some extent mass common language skills and aesthetic-speech ideals. The press picks up and repeatedly uses the well-known in oral speech turnover, so there is a «fashion» for stable momentum, caught in the center of public attention. It is reflected very accurately and immediately in the headlines.

Based on research by N.S. Valgina (Valgina, 1994: 57-58), let us focus on the main features of the language of the newspaper, also illustrating their own examples of phraseological units-headlines:

1. Among the neutral lexical means in the headings are actively used: socio-political terminology, scientific, technical and industrial terms, nomenclature units, geographical names, job titles, newspapers, magazines, etc.: Budget winter («Express K», January 14, 2015); Double bottom «new Euraism» (www.zona.kz); Chop the molecule into a fork («Time», January 26, 2015). The language of the newspaper is characterized by the alternation of expression and of the standard, i.e. moves from the emotive language in the standard. Appear and become clichés metaphors such as the cold war, new thinking, arms race, perestroika, etc. In standard templates and clichés almost immediately switched expressions, for example, an era of great change; Mission possible to protect (www.stan.kz); Kazakhstan may become a regional hub for the solution of economic disputes («Letters», August 13, 2015).

2. Characteristic metaphorical use of medical, military and sports terms: The jazz Sector (www. kapital.kz); Tip-off for the Prosecutor («Time», 15 August 2016); Mission accomplished («Evening Almaty», 14 January 2016).
3. Publicistic style is inherent in the formation of nouns with suffixes (teaching, computerization, voucher, ascetic), prefixes (super-task, interzonal, antifascist). In the headlines among the sociopolitical, as well as evaluative vocabulary is widely represented word composition (fraud, ineffective): Legalization: without fraud («Liter», December 19, 2015); Electric Conflict of interest («Time», October 7, 2015).

4. In the news headlines, abbreviations are used (ROC, OSCE, RK, UN) and compound words (highway, pseudo, photo festival, business school, rock-star): The Funds of the SAPF intend to use to support banks («Caravan», January 14, 2015); The Treasury named the best University in the Turkic countries («Letters», January 22, 2016).

5. In the headlines among the evaluation of vocabulary common unit suffixes of the reduced colouring (hype, window dressing, mitting): See the oncoming lane! («Time», November 20, 2015); Who needs hype («Banner of labor», November 20, 2015).

6. Quite often in the headings used inversion, updating, repetition, question and answer and call incentive forms, etc.: And build, and demolish! («Time», January 27, 2015) call; Waiter, salt and tequila! («Express K», January 27, 2015) incentive form.

7. Usual features of titles are generalized-personal and indefinite-personal, impersonal sentences (tell us pass; in a note reported): Rally! («Time», September 30, 2015); Named the brightest passengers of the year («Express K», December 26, 2015).

8. In the headlines actively used expressive syntax, different types of nominative, connecting and parceled constructions, question-and-answer constructions-all of them contribute to the overall manifestation of the contact-setting function («MissInstitute»,» Miss-University»,» Mini-miss»): Car! No, luxury? («Time», October 6, 2015); Do you like to ride? Ride! (Express K, June 15, 2015).

9. Various figurative means (tropes, figures, phraseological phrases, proverbs, sayings, idioms, etc.) are widely used in the titles, which are often transformed in the right way for a journalist. Methods of contamination, collisions of meaning, the updates of collocations, the usual speech of the formulas have the genre-compositional dependence and make it expressive, actively influencing the reader: Knights of the buffet («Express K», January 10, 2015); This is a sweet word - scholarship («Express K», 25 January 2016).

10. Oversaturation of the language of mass media by Americanisms, a large number of jargon 
and obscene vocabulary in it, violation of the normal pace and normative intonation pattern of speech is also peculiar to the titles: We only dream of the Playoffs («Time», January 27, 2016); Fake control (www.klive.kz).

11. Another distinctive feature of the language of the newspaper in recent years, and the one that catches eye, is the so-called «banter». Sociologists L. Gudkov and B. Dubinin give a definition of this phenomenon: «Banter - the kind of intellectual judgement, consisting in the reduction of characters through a demonstrative use of them in the parody context» (Karaulov, 2003: 220). We also recorded the use of banter in the headlines: Yes, long live corruption! («Time», October 2, 2015); Rooms are more expensive and penalties are less («Evening Almaty», December 5, 2015).

12. Headlines, as well as newspaper texts themselves, are oversaturated with colloquial and colloquial units, which often reduce newspaper speech to the level of everyday conversation: Cool! You hit the star! («Time», December 23, 2015); Under the auspices of the primary (www.contur. $\mathrm{kz}$ ); Akim lights («Evening Almaty», December 22, 2015); He lit not only on the field (www.vecher.kz).

The modern press often uses new words that cannot exist «outside the text». These include borrowed words, which are formed by the traditional corpus of word-formative means: prefixes, suffixes, affixes, combining several words of one language or different languages. This trend has also affected the headlines.

B. H. Hasanov noted that the constant contact of the Kazakh people with other nationalities and contact in languages, a plethora of kazachisms were produced, most of which are related to socioeconomic conditions, lifestyle, established rules for the behavior of the Kazakhs, their material and spiritual culture, family life of the Kazakhs (Khasanov, 1990: 165).

The modern Russian-language Newspapers, which cater to a wide range of readers, not only reflect the events occurring in the country, but also make whole groups of words enter into the vocabulary of the language and turn usage of whole groups of words from passive vocabulary to active.

A specific feature of the Kazakh language of the newspaper was the use of Kazakh words in Russian, while there may be an update of the meaning of already borrowed kazakhisms:

Let Shanyrak be high (Express K, October 20, 2015). Shanyrak - a structural element that crowns the dome of the yurt in the form of a lattice cross, inscribed in a circle, is designed to hold the side elements of the dome - uyks and create an opening for sunlight and smoke from the hearth.

Hockey is played by real horsemen (Express $\mathrm{K}$, February 20, 2017). The horseman is not a man prancing horse, but the one played hockey.

Kui while hot («Express K», 20 February 2017) kui - a piece of music (notation ethnographic concepts). Zorro in Malachi (Express K, February 14, 2017) Malachi is a large fur hat with wide ear covers.

The horse for the sogym will stop, in a burning yurt will enter («Express K», February 17, 2017) sogym (harvesting meat for the winter).

Ainalaiyn Jolie («Express K», 14 February 2017) Ainalayin (adjective) means «cute».

«Oibai!» cried Batman («Express K», 31 August 2016). Oibai is interjection denoting oi, oh, expressing fear, fear, indignation, frustration and surprise.

Baiga for survival («Express K», February 2, 2017) Baiga - horse racing, the name of the Kazakh national game.

Tokmobile with the horn «Ni Hao» («Ekpress K», February 15, 2017) Tok refers to electrical current in Russian. The article refers to the beginning of the production of Chinese electric vehicles.

Tokolistic scenario («Time», September 16, 2015). In this example, we can observe grammatical interference. The Kazakh word tokal («second wife») under the influence of Russian suffixes and the process of coordination of cases is russified, acquires the grammatical form of the Russian language.

In the given examples the expansion of lexical structure of the Russian language at the expense of the Kazakh «inclusions», borrowings is noticeable. Under inclusions we, after M.M. Kopylenko, understand «the foreign language component of the text, which belongs to a language different from that in which the text is composed, is felt in full and is not motivated by the subject-logical content of the content reported» (Kopylenko, 1986: 8). Kazakh word-units of other spiritual and cultural elements are included in the Russian language, reflecting other people's features of perception of the world, values, phenomena and artifacts. However they mastered the Russian language to a greater or lesser degree of being organically ordered, bringing to communication new categories, relevant to the residents of the common territory and a common communicative space (Suleymenova, 2011: 93).

The headline is open for interaction with other texts, with the recipient's presuppositions system, which determines the effectiveness and 
completeness of the message perception. According to T. Van Dijk, «the basis of mental schemes are abstract knowledge about stereotypical events and situations, and personal views of native speakers, accumulating their prior individual experiences, attitudes and intentions, feelings and emotions»" (Dijk, 1989: 102). The problem of intertextuality is directly related to the problem of understanding the text and its interpretation. Intertextuality, proposed by M.M. Bakhtin is a text that directly or indirectly refers to other people's texts and exists in the form of a «quote mosaic». It is characteristic of all forms of text formation in society.

The discursive space of the headline is a natural source of indirect-derivative nomination signs capable of representing simultaneously social, outlook and linguistic information caused by semiotic, situational and socio-cultural factors. It has a close connection with the processes of generating, processing, transforming and transmitting information, organized as a text, taken in the context event aspect, together with pragmatic, socio-cultural, psychological, paralinguistic and other factors.

Thus, the basis of mass communication as a conductor of information is a system, the unit of which is the text.

\section{Research results}

The title carries certain information. Titles are always informative, as they serve as a constant source of something new.

The linguistic features of titles can be summarized as follows:

1. Variability of syntactic structure. This is often a one of a nominative sentence. Meet fully constructed simple limited sentences. Simple common sentences are widely presented in the headlines. Complex sentences are very rare in headlines. There are headings in the form of interrogative sentences.

2. The widespread use of the ellipse, that is, omission of professional and sometimes significant words in order to give the title catchiness. A short headline is more quickly perceived by the reader, since its unusual form arouses interest and encourages the reader to read a newspaper article.

3. Abbreviated words in newspaper headlines. The use of abbreviations and acronyms is often used in the headlines of articles, which complicates the understanding of the text. Abbreviations are divided into accepted and occasional (random). It is interesting to note that it is easier to decipher occasional abbreviations. They exist only within this text and usually given at the beginning or in the middle of the text.

4. In any logically coherent verbal piece there are words, according to which you can with greater confidence define its main subject. For the headline, this feature becomes crucial. The headline, including the transformed phraseological-headline, can be considered as «nomination of a certain event, process, state, and a certain situation of reality...» (Dijk, 1989: 102).

In the case of transformation of the finished phraseological unit used as the title, the internal core of the secondary nomination is the dominant feature of the primary nominee, which acts as a distinctive. It is generally recognized that the secondary nomination, based on the repeated naming of the previously named object or phenomenon, is in opposition to the primary nomination and forms, as a rule, a system of hyperonym-hyponym.

\section{Conclusion}

A headline is a type of text that has most of the text-forming categories. The headline is characterized by integrity, textual design, intertextuality, targeting, semantic and structural completeness and wholeness, which determine the conditions for the implementation of the objectives of the functions of the media and the effectiveness of communicative influence.

The headline of newspaper texts and news sites, as the most readable component of any media, becomes the quintessential to the entire content of the text; a semiotic unit representing various types of cultural texts; metatextual unit, directly (often at the level of associations) correlating with the text it denotes; primary or secondary (in the case of precedent texts, the transformation of phraseological units, etc.) nominative unit; coding prospective (introducing the reader to the content of the text) and decoding retrospective (allowing to understand the content of the text after reading it) unit; a multifunctional unit that supports the thematic and aesthetic integrity of the text, optimally performing communicative, informative, appellative/influencing, expressive-emotional, advertising, integrative, graphic-excretory and other functions; a polyintential unit capable of expressing the reference (title $\rightarrow$ reality), creative (text $\rightarrow$ communicative installation of the author), receptive (text $\rightarrow$ perception and experience of the recipient) functions. 


\section{References}

Agricola E. (1979). Text structure - Text analyses - Information kern. Leipzig, 109 p.

Amzin A. Novostnaya internet-zhurnalistika [News online-journalism]. 10.06.2016. http://alex-alex.ru (In Russian)

Ernst R. (2005). Discourse analysis: news language. Verlag, 18 p.

Karaulov Yu.N. (2003). Russkiy yazyk i yazykovaya lichnost [Russian language and language personality]. Moscow: LKI, 167 p. (In Russian)

Khasanov B.Kh. (1990). Kazakhsko-russkoye khudozhestvenno-literaturnoye dvuyazychiye [Kazakh-Russian artistic and literary bilingualism.]. Alma-Ata: Rauan, 192 p. (In Russian)

Kopylenko M.M. (1986). Belorusskiye vkrapleniya v russkikh khudozhestvennykh tekstakh: funktsii. struktura. kommunikativnaya priroda [Belarusian inclusions in Russian artistic texts: functions, structure, communicative nature]. Grodno, 125 p. (In Russian)

Kostomarov V.G. (1965). Iz nablyudeniy za yazykom gazety: gazetnyye zagolovki [From the observations of the language of the newspaper: newspaper headlines]. Moscow: Mysl, P. 163-181 (In Russian)

Kozhabekova R.T. (2002). Baspasoz betindegi takyryptardyn frazeologiyalanu ereksheligi [Peculiarities of phraseology in the press]. Almaty, 140 p. (In Kazakh)

Lazareva E.A. (1989). Zagolovok v gazete [Headline in newspaper]. Sverdlovsk: Izd-vo Uralskogo universiteta, 82 p. (In Russian)

Rozental D.E. (1981). Stilistika gazetnykh zhanrov [Stylistics of newspaper genres]. Moscow, 230 p. (In Russian)

Semenets O.P. (2004). Pretsedentnyi tekst $v$ yazyke gazety: dinamika diskursa 50-90-kh godov [The case text in the language of the newspaper: the dynamics of the discourse of the 50-90s].Saint Petersburg, 22 p. (In Russian)

Stepanova M.A. (2006). Dialogichnost kommunikatsii v zhanre intervyu v sovremennoy nemetskoy presse (na materiale zhurnala «Der Spiegel») [Dialogue of communication in the genre of interviews in the modern German press (on the material of the magazine «Der Spiegel»)]. Moscow, 259 p. (In Russian)

Suleymenova E.D. (2011). Yazykovyye protsessy i politika: monografiya [Language processes and politics: monograph]. Almaty: Kazak universiteti, 117 p. (In Russian)

Teun A. van Dijk (1989). Language. Cognition Communication. London, 312 p.

Valgina N.S. (1994). Funktsionalnyye stili russkogo yazyka: uchebnoye posobiye [Functional styles of the Russian language: a tutorial]. Moscow, 224 p. (In Russian)

Vomperskiy V.A. (1966). K izucheniyu sintaksicheskoy struktury gazetnogo zagolovka [To the study of the syntactic structure of the newspaper headline]. Alma-Ata, P. 82-85 (In Russian)

\section{Әдебиеттер}

Амзин А. Новостная интернет-журналистика // http://alex-alex.ru

Караулов Ю.Н. Русский язык и языковая личность. - М.: ЛКИ, 2003. - 167 с.

Agricola E. Textstruktur - Textanalyse - Informationskern. - Leipzig, 1979. - 109 p.

Ernst R. Discourse analysis: news language. - GRIN Verlag, 2005. - 18 p.

Семенец О.П. Прецедентный текст в языке газеты: динамика дискурса 50-90-х годов. - СПб., 2004. - 22 с.

Степанова М.А. Диалогичность коммуникации в жанре интервью в современной немецкой прессе (на материале журнала «Der Spiegel»). - M., 2006. - 259 с.

Розенталь Д.Э. Стилистика газетных жанров. - М., 1981. - 230 с.

Қожабекова Р.Т. Баспасөз бетіндегі тақырыптардың фразеологиялану ерекшелігі: филол. ғылым. канд. дис. - Алматы, 2002. - 140 б.

Вомперский В.А. К изучению синтаксической структуры газетного заголовка//Искусство публицистики (проблемы теории и мастерства): тез. докл. на респуб. науч. конф-семинаре. - Алма-Ата, 1966. - С. 82-85

Костомаров В.Г. Из наблюдений за языком газеты: газетные заголовки//Из опыта преподавания русского языка нерусским. - М.: Мысль, 1965. - С. 163-181

Лазарева Э.А. Заголовок в газете. - Свердловск: Изд-во Уральского университета, 1989. - 82 с.

Валгина Н.С. Функциональные стили русского языка: учебное пособие. - М., 1994. — 224 с.

Хасанов Б.Х. Казахско-русское художественно-литературное двуязычие. - Алма-Ата: Рауан, 1990. - 192 с.

Сулейменова Э.Д. Языковые процессы и политика: монография. - Алматы: Қазақ университеті, 2011. - 117 с.

Копыленко М.М. Белорусские вкрапления в русских художественных текстах: функции, структура, коммуникативная природа//Словообразовние и коммуникативная деривация в славянских языках. - Гродно, 1986. - 125 с.

Дейк Т.А. Познание. Коммуникация/пер. с англ. - М.: Прогресс, 1989. - 312 с. 